\title{
Faculty Involvement in Student Organizations
}

\author{
Louis L. Warren ${ }^{1}$ \\ ${ }^{1}$ East Carolina University, Greenville, NC, USA \\ Correspondence: Louis L. Warren, East Carolina University, Greenville, NC, USA.
}

Received: April 23, 2017

Accepted: May 15, 2017

Online Published: May 26, 2017

doi:10.5430/irhe.v2n2p51

URL: https://doi.org/10.5430/irhe.v2n2p51

\begin{abstract}
This article examines how college students benefit from faculty being involved in their student organizations. Substantial research has been carried out on how such involvement impacts college students, for example, on their skills, values, aspirations, attitudes, job and even personality characteristics. Beyond the opportunities provided for students to gain academically-related information, such interactions have a wider impact on students' general ways of thinking, methods of solving problems, and interests in life goals. Increased involvement of faculty with students' programs is one way of increasing students' satisfaction with academic and other non-academic programs, thus helping to retain highly motivated and qualified individuals who can remain loyal to the learning institution and support its programs. Such interactions also foster students' occupational decisions, increase students' persistence at the college, influence academic and intellectual development, and foster social or personal development. Research on the impact of faculty-student interaction concludes that more is better.
\end{abstract}

Keywords: Student organizations, faculty involvement, higher education, motivation

\section{Introduction}

Higher education student organizations provide students opportunities to supplement their formal education with extra-curricular academic programs, learn leadership skills, and to pursue different non-academic interests. While there are several reasons good reasons for students to join such organizations, increased interactions with faculty is a significant benefit in doing so. Students receive richer and more meaningful experiences in their student organizations when faculty are actively involved in them. Faculty-student interaction assists in the facilitation of student engagement. Research supports that there is a relationship between faculty involvement in student issues, and multiple educational gains, which include academic skill development, occupational values, leadership ability and benefits in educational aspirations (Wood \& Palmer, 2014). The more interactions faculty has with students inside and outside the class, the greater the students' gains would be in terms of institutional satisfaction and student development.

Faculty involvement of faculty in higher education settings have been extensively studied and found that it holds many benefits for students. They provide rewarding and unique opportunities for students to obtain practical skills and improve the put-of-classroom experience. Being involved in student organizations helps students to gain higher leadership skills, great connections or networking, increases their satisfaction level, and advances their professional development (Kezar \& Maxey, 2014). The benefits involved are found professionally, personally and socially. Most students find that through such involvement, they have grown as leaders, and have confidence to work in groups or to lead in teams.

As important additions to the student organizations, faculty guide students or organization members by improving this experience, and operating the organization effectively. They also act as confidants in organizational and individual-related matters, rendering knowledge about the institution's practices and history, and offering valuable framework to the activities of the student organizations (Gallagher, 2012). In universities and colleges, the general functions of faculty are research, teaching, and service to the institution, the community, and the profession. The extent to which they are expected to fulfill these roles depends on how their particular institutes define their mission. Faculty members can serve as advisers and mentors to students, and members of different committees.

\section{Benefits of Faculty Involvement to College Students}

Study on student organizations and faculty advisor programs have shown that the faculty department is an essential determining factor in college students' personal and intellectual development, persistence and satisfaction. The more 
college students engage with faculty (inside and outside the classroom), the higher the chance for student satisfaction, retention and success. Other positive outcomes include increased persistence, development of critical thinking skills, career aspiration, self confidence, and a sense of self worth. Dunkel and Schul (1998) also noted in their research that there are many benefits that motivate faculty to get involved in student associations. These include recognition from the institution, organizations of the students; observing the growth of students during their matriculation, and serving as mentors and job references for students.

Student interaction and involvement with faculty members, (inside and outside the class) have been regarded as determining factors in the personal and intellectual development and satisfaction of a student (Townsend, MacBeath \& Barwani, 2011). Frequent relations with faculty are strongly connected to satisfaction, which means it could be a greatly productive activity in most colleges. Such interactions have been shown to enhance the students' quality of learning and educational experience. In addition, the quality of interaction between faculty and students helps students to develop persistence toward completing their studies, and also, decreases the rates of dropout (In Scott \& In Sims, 2016). There is an association between such involvement with increased performance and better grades. The faculty brings their expertise to student organizations and through their interaction; any deficiency in the education system can be brought forth for discussion, and in agreement, solutions to improve the situation are reached.

Student - faculty relationship promotes student engagements, contributes to students' aspirations, boosts academic self-confidence, and increases motivation to learn. Different education theories suggest that learning is naturally social; and support why it is important to have faculty involved in students issues (Kezar \& Maxey, 2014). These well-established learning theories include social learning theory, situated learning theory, and the neuroscience research. They have shown why and how faculty and student interactions are significant in improving learning. According to Maxey \& Kezar, (2016), in-class and out-of-class interactions positively influence students' views of their college environment and their satisfaction. Research has shown that these interactions tend to decrease students' dropout rates from college, and also increases persistence, which is enhanced by the quality of faculty-student relationships, and the amount of time they spent together.

Faculty members have deeper knowledge of college and its culture from the administrative perspective. When students are given the opportunity to interact with faculty, they are able to play an active role and make considerable contributions in upholding the long-term values and goals of campus. This can be achieved through involvement in making decisions especially those pertaining to students' matters, such as curriculum planning; or giving opinions on academic or non-academic issues, for instance, how to improve learning inside and out-of-classroom. This increases their level of satisfaction and helps them to build their career in an engaging environment. It also creates a sense of belonging among the students. Failure to be in agreement on issues touching them can result in serious impediments to programs of the college.

Being in a student organization is an opportunity to establish a number of connections that one may need in the future. Student organizations are forums where several students and other professionals meet. Through consultation and assistance from faculty, they can invite speakers such as, scholars, managers and other professionals, to talk to them on different subjects or topics. These interactions are beneficial because students can get job opportunities. It is possible to get connected to people experienced in the area of expertise they are in, or in higher positions in organizations. Networking and connections are vital when a student is searching for employment after graduation. It is a good opportunity for a student to meet people out there who are in the same field, and are ahead of him or her. In addition, such inclusive programs provide a greater access to career information, and foster leadership development (Buch \& Barron, 2012).

This also provides them the opportunity to grow their leadership skills, while still making significant differences in their communities (Brinkmann, 2016). For instance, faculty can help students to be involved in student-based learning communities, which affords them valuable opportunities to practice or even acquire leadership skills that can serve them well in their chosen careers. Leadership involves action and this means that leadership skills cannot be gained in the classroom. Once a person joins a student organization and relates with faculty effectively, he is in a position to advance his or her skills and become better to lead and influence others in the college. The ability to go through tasks and action plans is significant for a leader. In most cases, faculty members are experienced and knowledgeable, and because of this, they are able to provide professional help to students. This may include helping students to become critical thinkers, creative in problem solving, and practical when approaching issues affecting their lives (Gallagher, 2012).

In every institution, there are lecturers or teachers whose vision rises above the classroom - even beyond their departments and teams. Such teachers realize that students' school experiences rely not only on interactions with 
individual teachers, but on the complex systems of the college, as well. Such awareness prompts lecturers to desire to influence change and this is demonstrated in their relation with students, trying to empower them to become a better people. Student leaders reap a lot of benefits and rewards due to their involvement with college student organizations. Besides enjoying the high opinion of their peers, they get opportunities to meet different faculty, which exposes them to different cultures and personalities. According to Wood \& Palmer, (2014), these interactions with faculty help them grow in practical competence and self confidence as they discover how to deal with groups' financial resources and their time. In addition, due to the challenges encountered through leadership, students are able to get out of their comfort zones and learn how to think critically and respond to situations fast, which enables them to be more responsive and reflective.

Mentoring in student organizations is very important. Advisors and officers particularly play a vital role in mentoring fresh members to ensure that they cope well in the union. Students who receive such mentorship are able to execute their responsibilities and duties effectively, and are even able to provide help and advice to other students, on how to address issues that may arise during their college days (Laverick, 2016). These challenges may be curricular or even personal life issues. Mentorship is all about empowering, nurturing, growing and shaping a person. It is also about building integrity, relationships and perpetual learning. Success is evaluated in changed lives, lasting values and strong character, rather than temporal achievement and material gain.

Mentoring establishes closer relationships among students and faculty and through this, trust is built outside the classroom, which is helpful because students can share their concerns and needs freely, and thus, receive assistance on how to address their concerns. Such relationships are a pillar in building an environment of trust, whereby students can draw wisdom and knowledge from faculty's massive experiences. This is important because it fosters problem solving and creative thinking abilities among students. Trust creates confidence and eliminates fear, which means that students can express their ideas and opinions in a safe and comfortable environment (Hamza \& Griffith, 2006). Informal (out-of-class) interaction helps students to be more engaged, motivated and actively involved in learning processes (Komarraju \& Musulkin \& Bhattacharya, 2010). This is because in such environments, faculty and students can spend more time together in a free environment where there can be more engagement.

There is an existing correlation between participation in student organizations and contentment, especially for the minority group. When faculty is involved in these associations, they tend to create an environment of cultural advocacy and validation, and also make the school become a cultural center and a home away from home for minority student (Wood \& Palmer, (2014). Such environment provides the students with critical opportunities to nurture or establish supportive relationships with other students, staff and faculty. They are also able to engage in educational and purposeful activities freely. This expands their opportunity to grow and develop, and even learn to support each other.

In some colleges, the faculty has sessions to meet with students to offer advice, guidance and counseling, and provide resources that are important to the development of the student. This approach is an outreach that tends to bring resources directly to the learners. The ability to share professional ideas in workshops is a need-based program that is important in meeting students' needs (Townsend, MacBeath, \& Barwani, 2011). This can be a method of professional development or a direct preparation for students' future careers, as they provide them with expertise, connections, and better understanding of what they are required to achieve.

Faculty serve as intellectual advisers to students, with some reporting that having a close relationship with faculty has been the most positive aspect of their educational experience, as well as a remarkable influence on their career plans (Sandeen, 2000). Faculty who encourage service learning as an element of their teaching encourages students to get involved in community service-programs. Those who go through such programs volunteer much of their time in local schools, hospitals, homeless institutions and retirement communities. To such students, these activities are a useful application of their academic skills and of the values of their institutions.

When the faculty engages in student organizations, there is a possibility of understanding better the needs of students. Student organizations are based on the welfare of students, and thus, students are likely to open up to faculty on matters affecting their lives -academics or personal. When the administration is involved in these organizations, they create an environment where they can listen to students' complaints and thereafter, consider them when making decisions. Faculty that is actively involved in students' welfare makes themselves approachable and easily accessible (Laverick, 2016). This enhances communication and helps to eradicate the notion of an authoritative and harsh administration, thus creating a sense of belonging for students.

With the involvement of faculty in student organizations, research has shown that there is a positive influence to the student since his or her engagement and interest in studies is increased. This may be attributed to faculty's 
enthusiasm for their areas of specialty, which tends to encourage students commitment to their studies. In addition, when students feel appreciated and respected by their teachers, there is a possibility for students to be motivated. Faculty's involvement in students learning is a sign of approachability, accessibility and willingness to help them develop their careers to higher levels (Kezar \& Maxey, 2014). In case of disconnection between students and faculty, there is always a feeling of isolation, which may lead to poor relationships, thus leading to less motivation, lack of engagement, poor student success, and lower academic aspirations

If faculty gets involved with student organizations as part of a team, and not a leader, they are able to provide perspective, insight and guidance to students. Team mates can help each other in developing organizational programs, and discussing goals and directions of their organizations. They can also articulate procedures and policies of the college, and help each other understand the policies (Buch \& Barron, 2012). For students, being involved in such processes helps them grow in their abilities and their professions. Student organizations also help one develop soft skills. These skills include learning how to interact with people. It is noteworthy at this point that colleges are some of the places where a person meets people from all walks of life. Student organizations create avenues where people are able to share ideas and skills, and thus build on their general skills. These skills may be useful in and after campus as they equip one for general life issues faced in campus and even after.

Student organizations help one understand and appreciate diversity. Diversity helps to get rid of racial discrimination, and any form of prejudice based on sex (In Scott \& In Sims, 2016). It is in universities and colleges that people get to intermingle with many other students from all corners of the world. Joining student organizations promotes interaction with these people. Involvement of faculty also helps to fight some vices such as discrimination and racism. This is because together with student leaders, they can form an alliance to promote positive social behaviors. In addition, working together with a college's faculty makes it easier to eliminate challenges of racial oppression, and helps to develop transformative leaders. No college would openly promote racism since this would greatly affect their reputation.

\section{Conclusion}

Student organizations are managed by student leaders who ensure that they are run in line with college rules. Such organizations provide opportunities for students to learn different things and share ideas outside the classroom. Faculty involvement in student organizations is related to students' success, development and widened experiences. This interaction assists in the facilitation of student engagement. Previous studies have shown that there is connection between faculty engagement in student issues, and wide range of educational gains, which comprise of educational skill development, occupational values, leadership skills, and promotion of educational aspirations (Wood \& Palmer, 2014). Faculty members have a significant role to influence college students' dedication through their involvement with students' issues both inside and outside their classes. In addition, a supportive faculty helps to nurture accommodating and friendly platforms for students to attain higher academic results. Thus, it is crucial for them to understand the influence they have in impacting students through their interactions, and make an effort to foster them.

\section{References}

Brinkmann, R. (2016). Sustainability: An introduction.

Buch, K., \& Barron, K. E. (2012). Discipline-Centered Learning Communities: New Directions for Teaching and Learning. New York: Wiley.

Dunkel, N. W., \& Schuh, J. H. (1998). Advising student groups and organizations. San Francisco: Jossey-Bass.

Gallagher, D. R. (2012). Environmental leadership: A reference handbook. Thousand Oaks, Calif: SAGE Publications, Inc. https://doi.org/10.4135/9781452218601

Hamza, M. K., \& Griffith, K. G. (2006). Fostering problem Solving and Creative thinking in Classroom: Cultivating a Creative Mind. National Forum of Applied Educational Research Journal-electronic, 19(3).

Kezar, A., \& Maxey, D. (2014). Faculty Matter: So why doesn't everyone think so? Retrieved from https://www.nea.org/assets/docs/HE/e-Kezar.pdf

Komarraju, M., Musulkin, S., \& Bhattacharya, G. (2010). Role of Student-Faculty Interactions in Developing College Students' Academic Self-Concept, Motivation, and Achievement. Journal of College Student Development, 51(3), 332-342. The Johns Hopkins University Press. https://doi.org/10.1353/csd.0.0137

Laverick, D. A. M. (2016). Mentoring processes in higher education. 
Maxey, D., \& Kezar, A. J. (2016). Envisioning the faculty for the twenty-first century: Moving to a mission-oriented and learner-centered model. New Brunswick, New Jersey: Rutgers University Press.

Sandeen, A. (2000). Improving Leadership in Student Affairs Administration: A Case Approach. Springfield: Charles C Thomas Publisher, LTD.

Scott, C. L., \& Sims, J. D. (2016). Developing workforce diversity programs, curriculum, and degrees in higher education.

Townsend, T., MacBeath, J., \& Barwani, T. A. (2011). International handbook of leadership for learning. Dordrecht: Springer. https://doi.org/10.1007/978-94-007-1350-5

Wood, L., \& Palmer, R. T. (2014). Black Men in Higher Education: A Guide to Ensuring Student Success. Routledge. 